\title{
Clinical Evidence for Targeting NAD Therapeutically
}

\author{
Dina Radenkovic ${ }^{1}$ * Reason $^{2}$ and Eric Verdin ${ }^{3}$ \\ 1 Health Longevity Performance Optimisation Institute, Cambridge CB22 5NE, UK \\ 2 Fight Aging!, 4736 Onondaga Blvd, PMB 179, Syracuse, NY 13219, USA; reason@fightaging.org \\ 3 Buck Institute for Research on Aging, Novato, CA 94945, USA; everdin@buckinstitute.org \\ * Correspondence: drdina@hlpo.life; Tel.: +44-7818673663
}

Received: 18 August 2020; Accepted: 10 September 2020; Published: 15 September 2020

\begin{abstract}
Nicotinamide adenine dinucleotide (NAD) pharmacology is a promising class of treatments for age-related conditions that are likely to have a favorable side effect profile for human use, given the widespread use of the NAD precursor vitamin B3 supplements. However, despite several decades of active investigation and numerous possible biochemical mechanisms of action suggested, only a small number of randomized and adequately powered clinical trials of NAD upregulation as a therapeutic strategy have taken place. We conducted a systematic review of the literature, following the PRISMA guidelines, in an attempt to determine whether or not the human clinical trials performed to date support the potential benefits of NAD supplementation in a range of skin, metabolic and age-related conditions. In addition, we sought medical indications that have yielded the most promising results in the limited studies to date. We conclude that promising, yet still speculative, results have been reported for the treatment of psoriasis and enhancement of skeletal muscle activity. However, further trials are required to determine the optimal method of raising NAD levels, identifying the target conditions, and comparisons to the present standard of care for these conditions. Lastly, pharmacological methods that increase NAD levels should also be directly compared to physiological means of raising NAD levels, such as exercise programs and dietary interventions that are tailored to older individuals, and which may be more effective.
\end{abstract}

Keywords: nicotinamide adenine dinucleotide; NAD; pharmacology

\section{Introduction}

The cofactor nicotinamide adenine dinucleotide (NAD) is an important metabolic regulator of cellular redox reactions and a co-factor or a co-substrate for key enzymes essential for normal cellular function in different tissues. Known as NAD+ in its oxidized state and NADH in its reduced state, it was first described more than a century ago as a molecule in the electron transport chain in the metabolic reduction-oxidation reactions in mitochondria [1]. Poly(ADP-ribose) polymerases (PARPs), a group of enzymes that catalyze the transfer of ADP-ribose to target proteins, use NAD as a cofactor [2]. PARPs regulate many important cellular functions, including expression of transcription factors, gene expression and DNA repair. More recent interest in NAD emerged from research into the role of sirtuins, NAD-dependent deacylases, after the discovery that Sirtuin 2 is an NAD+-dependent histone deacetylase [3]. Sirtuins influence many important cellular processes, including inflammation, bioenergetics, circadian rhythm generation, and cell growth, all fundamental to cellular aging. These pathways place NAD at the center of cellular metabolism, mitochondrial function, and biological processes of aging.

Most human cells must rely on de novo creation of NAD from a variety of building blocks (Figure 1) [4]. NAD can be synthesized de novo from tryptophan via the kynurenine pathway or from nicotinic acid via the Preiss-Handler pathway [5]. However, the bulk of NAD synthesis in 
cells is generated via the NAD salvage pathways acting on the precursor molecule nicotinamide. Nicotinamide, the dominant NAD precursor, originates from the diet or can be produced by the activity of a variety of NAD hydrolases that include CD38/CD157, PARPs and Sirtuins [6].

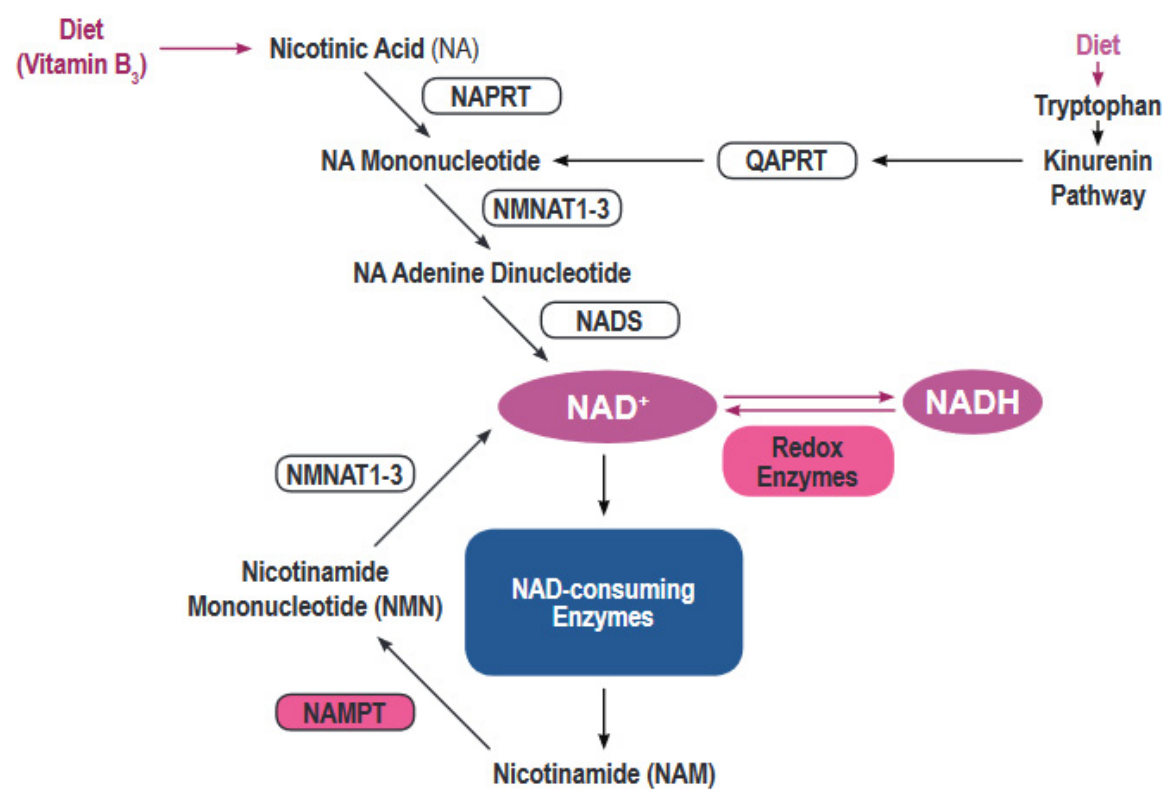

Figure 1. Regulation of the nicotinamide adenine dinucleotide (NAD) metabolism. The figure shows the main synthesis pathways of NAD including the de novo synthesis via the kynurenine pathway or from nicotinic acid and the salvage pathways.

NAD levels decline with increasing age, as the activities of both the salvage pathways and de novo synthesis are reduced, the result of altered levels of rate-limiting enzymes and precursors. There is also growing evidence that the activity of specific NAD hydrolases, particularly CD38, increases in specific tissues during aging [7]. Evidence from animal studies indicates that interventions that increase NAD levels produce numerous benefits on the overall cardiometabolic health and immune function [4]. A fall in NAD levels might be prevented with supplementation with NAD precursors, such as nicotinamide, nicotinic acid, nicotinamide mononucleotide (NMN), and nicotinamide riboside (NR). NMN and NR are believed to be orally bioavailable and feed into the NAD salvage pathway directly (NMN) or indirectly (NR via NMN) and thereby bypass a key rate-limiting step determined by the enzymatic activity of NAMPT which decreases with age. Both NMN and NR have received the most recent interest as promising future therapeutic strategies to raise NAD levels [8].

However, supplementation with NAD precursors is not the only way to increase NAD levels. Other possible approaches include strength training [9], upregulation of critical enzymes (e.g., rate-limiting NAMPT) involved in NAD salvage [10], and inhibiting NAD degradation (e.g., with bioavailable flavonoids to inhibit CD38) [11].

Evidence suggesting the benefits of NAD upregulation in humans has accumulated, but much of it involves the use of vitamin B3 and predates the most recent sirtuin-related expansion of knowledge of the role of NAD in cellular metabolism and aging. For example, daily niacin intake has been recommended for much of the past century. Furthermore, extensive literature already accompanies the use of high-dose niacin for dyslipidemias in the context of cardiovascular disease prevention [12,13]. However, the literature currently lacks a rigorous assessment of the potential role of NAD upregulation on healthspan using relevant surrogate biomarkers of aging.

A number of clinical trials have been conducted recently, with more underway, to rigorously assess NAD pharmacology in the context of aging and metabolic and age-related disease. These trials benefit from the more recent understanding of NAD and its relationships with important processes in cellular aging, and so NAD has been discussed as a therapeutic intervention for a range of age-related conditions, 
including immune decline (immunosenescence) and sterile chronic inflammation (inflammaging). De novo NAD synthesis is involved in the innate immune response of macrophages [14] and, indeed, the broader immune response, due to elevated cellular energy requirements during an acute immune response $[15,16]$.

More recently, NAD upregulation has been proposed as a prevention or treatment of viral illnesses and vaccine boosters. These are of particular interest for treating COVID-19, a new disease caused by the novel SARS-CoV-2 coronavirus. The elderly are at increased risk of mortality and morbidity of the COVID-19 infection, and pharmacological enhancement of NAD levels, which might have a beneficial effect on the biological processes of aging, might be particularly useful in this context. Thus far, no evidence of benefit has been reported, and it remains unclear as to whether upregulating NAD is an effective therapy for immune decline. Animal studies have suggested a double-edged sword situation regarding NAD and immunity where raising NAD levels might lead to increased activity of immune cells in inflammatory conditions $[15,17]$.

Considering all of the above, we have conducted a review of the literature in an attempt to determine whether or not the present human evidence for the potential benefits from NAD pharmacology supports an expansion of efforts to assess this approach to age-related conditions.

\section{Methods}

The review was conducted in accordance with the 2009 Preferred Reporting Items for Systematic Reviews and Meta-Analyses PRISMA Statement (Figure 2). MEDLINE (PubMed) and all databases across Web of Science were searched using search terms related to NAD supplementation in human studies and clinical outcomes. The search was limited to English language and adult human studies published up until 10 June 2020.

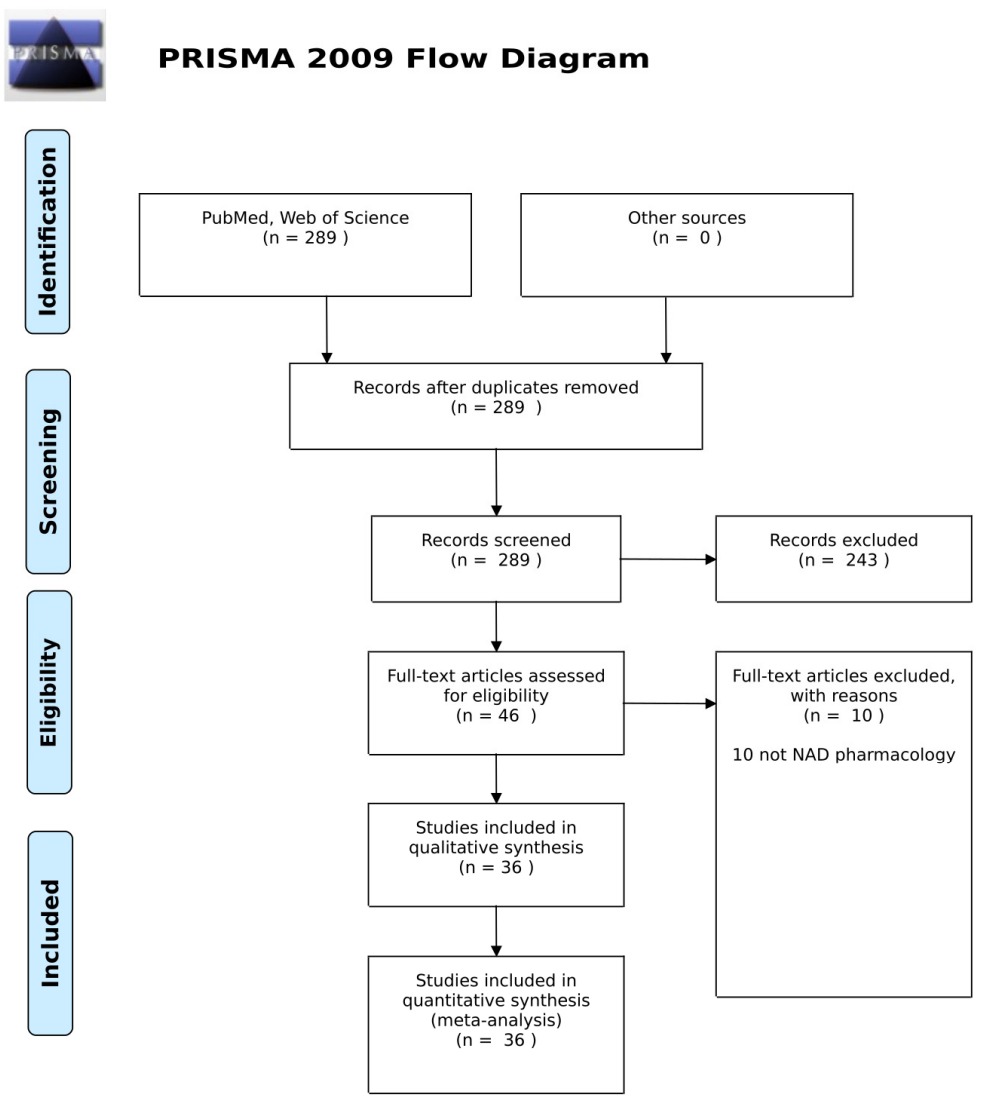

Figure 2. PRISMA 2009 flow diagram. 
Using the title and abstract, we screened articles against inclusion and exclusion criteria. Subsequently, two independent authors (R, DR) independently reviewed full texts against eligibility criteria for final selection. Any disagreements between the two reviewers were resolved by discussion. Studies were excluded if they were non-English, were not conducted in human patients, or did not focus on increasing NAD levels. A record was retained if the full text was available, and the authors reported human trial data on the upregulation of NAD levels or targeting NAD biochemistry, such as via administration of NAD.

In addition, the existing literature and ClinicalTrials.gov were searched for pending or ongoing clinical trials of NAD+ pharmacology that have yet to publish results.

\section{Results}

\subsection{Screening}

In the initial screen, 289 records were identified. All were reviewed to ensure relevance and full-text availability. Of these, 36 records met the eligibility requirements. The characteristics of these studies are summarized in Table 1, in that the authors reported human trial data for interventions based on NAD pharmacology.

Table 1. Studies of NAD pharmacology and related interventions.

\begin{tabular}{|c|c|c|}
\hline Study & Intervention & $\mathbf{N}$ \\
\hline $\begin{array}{c}\text { Controlled evaluation of nicotinamide adenine dinucleotide in the } \\
\text { treatment of chronic Schizophrenic patients, Kline et al., } 1967 \text { [18] } \\
\text { Oral NAD } 1 \text { or } 2 \text { g daily. No systemic improvement in either treatment } \\
\text { group. }\end{array}$ & NAD & 14 \\
\hline $\begin{array}{l}\text { Diphosphopyridine nucleotide in the treatment of schizophrenia, Kline } \\
\text { et al., } 1967 \text { [19] } \\
\text { Oral NAD } 1 \text { g or } 2 \text { g daily. No positive results were seen. }\end{array}$ & NAD & 20 \\
\hline $\begin{array}{l}\text { The behavioral effects of nicotinamide adenine dinucleotide in chronic } \\
\text { schizophrenia, Meltzer et al., } 1969 \text { [20] } \\
\text { Oral } 2 \text { g NAD daily for } 21 \text { days. NAD: After a single dose in volunteer } \\
\text { blood samples, not in the study population. No gross clinical } \\
\text { improvement was noted. }\end{array}$ & NAD & 10 \\
\hline $\begin{array}{l}\text { Nicotinic acid in the treatment of schizophrenia, Ban, } 1975 \text { [21] } \\
\text { Oral } 3000 \mathrm{mg} \text { nicotinic acid daily. Inferior to placebo. }\end{array}$ & Nicotinic acid & 86 \\
\hline $\begin{array}{l}\text { The coenzyme nicotinamide adenine dinucleotide (NADH) improves } \\
\text { the disability of parkinsonian patients, Birkmayer et al., } 1989 \text { [22] } \\
\text { Intravenous infusion of } 25 \mathrm{mg} \text { NADH daily for } 10-14 \text { days. } 21 \text { patients } \\
(61.7 \%) \text { showed a very good (better than } 30 \% \text { improvement of } \\
\text { disability; } 13 \text { patients }(38.3 \%) \text {, a moderate (up to 30\%) improvement. }\end{array}$ & $\mathrm{NADH}$ & 34 \\
\hline $\begin{array}{l}\text { Nicotinamide adenine dinucleotide (NADH)-A new therapeutic } \\
\text { approach to Parkinson's disease. Comparison of oral and parenteral } \\
\text { application, Birkmayer et al., } 1993 \text { [23] } \\
\text { Intravenous infusion and oral NADH, } 25-50 \mathrm{mg} / \text { day. } 19.3 \% \text { of the } \\
\text { patients showed a very good ( } 30-50 \% \text { ) improvement of disability; } 58.8 \% \\
\text { a moderate (10-30\%) improvement; } 21.8 \% \text { did not respond to NADH. }\end{array}$ & $\mathrm{NADH}$ & 885 \\
\hline $\begin{array}{c}\text { Treatment of Parkinson's disease with NADH, Dizdar et al., } 1994 \text { [24] } \\
\text { Intramuscular } 25 \text { mg NADH on days 1-4, 14, 28. No statistically } \\
\text { significant benefit. }\end{array}$ & $\mathrm{NADH}$ & 9 \\
\hline
\end{tabular}


Table 1. Cont.

\begin{tabular}{ccc}
\hline Study & Intervention & $\mathbf{N}$ \\
\hline Coenzyme nicotinamide adenine dinucleotide: New therapeutic & \\
approach for improving dementia of the Alzheimer type, Birkmayer, & \\
1996 [25] & NADH & 17 \\
$\begin{array}{c}\text { Oral } 10 \text { mg/day NADH for 8-12 weeks. Improvement in mini-mental } \\
\text { state examination and global deterioration scale. This open-label trial } \\
\text { represents a pilot study from which no definitive conclusion can be } \\
\text { drawn. }\end{array}$ & \\
\hline Nicotinic acid supplementation: Effects on niacin status, cytogenetic
\end{tabular}

Nicotinic acid supplementation: Effects on niacin status, cytogenetic damage, and poly(ADP-ribosylation) in lymphocytes of smokers, Hageman et al., 1998 [26]

Oral 0-100 mg/day nicotinic acid. NAD+: Small increase in PBMC. No evidence was found for a decrease in cigarette smoke-induced cytogenetic damage.

Therapeutic effects of oral NADH on the symptoms of patients with chronic fatigue syndrome, Forsyth et al, 1999 [27]

Oral $10 \mathrm{mg}$ NADH daily. A significant 31\% favorable response to NADH versus $8 \%$ to placebo.

No evidence for cognitive improvement from oral nicotinamide adenine dinucleotide (NADH) in dementia, Rainer et al., 2000 [28]

Oral $10 \mathrm{mg}$ NADH daily for 12 weeks. No evidence for any cognitive effect as defined by established psychometric tests.

European Nicotinamide Diabetes Intervention Trial (ENDIT): A

randomized controlled trial of intervention before the onset of type 1 diabetes, Gale et al., 2004 [29]

Oral $1.2 \mathrm{~g} / \mathrm{m}^{2}$ nicotinamide daily up to a maximum of $3 \mathrm{~g} /$ day for 5

years in two divided doses. No difference in the development of diabetes between the treatment groups.

Nicotinamide effects oxidative burst activity of neutrophils in patients

with poorly controlled type 2 diabetes mellitus, Osar et al., 2004 [30]

Oral $50 \mathrm{mg} / \mathrm{kg}$ nicotinamide daily for 1 month. Oxidative burst activity

Nicotinamide was greater in patients receiving nicotinamide.

Nicotinamide suppresses hyperphosphatemia in hemodialysis patients, Takahashi et al., 2004 [31]

Oral $500 \mathrm{mg}$ nicotinamide daily for 12 weeks increasing by $250 \mathrm{mg}$ every 2 weeks. NAD: $\sim 42 \%$ increase in blood levels. Increased serum

HDL cholesterol, decreased LDL cholesterol and phosphate.

In search for new antipsoriatic agents:
NAD+ topical composition, Wozniacka et al., 2006 [32]
$\begin{gathered}\text { Topical 1\% or 0.3\% NAD+ daily for } 4 \text { weeks. Topical NAD+ has an } \\ \text { antipsoriatic potential, similar to that of anthralin. }\end{gathered}$

A topical lipophilic niacin derivative increases NAD, epidermal differentiation and barrier function in photodamaged skin, Jacobson et al., 2007 [33]

Topical myristyl nicotinate $1-5 \%$ daily for $8-18$ weeks. NAD: 125\%

increase in the skin. MN treatment of photodamaged facial skin increased stratum corneum thickness by $70 \%$ and epidermal thickness

Myristyl nicotinate 16 and 60 by approximately $20 \%$.

\section{Skeletal muscle NAMPT is induced by exercise in humans, Costford et} al., 2010 [34]

Exercise: alternating day progressive 30-60-min interval protocol and Aerobic exercise 
Table 1. Cont.

\begin{tabular}{|c|c|c|}
\hline Study & Intervention & $\mathbf{N}$ \\
\hline $\begin{array}{l}\text { Treatment of Parkinson's disease with NADH, Dizdar et al., } 1994 \text { [24] } \\
\text { Intramuscular } 25 \text { mg NADH on days 1-4, 14, 28. No statistically } \\
\text { significant benefit. }\end{array}$ & $\mathrm{NADH}$ & 9 \\
\hline $\begin{array}{l}\text { The effect of antioxidant supplementation on fatigue during exercise: } \\
\text { Potential role for NAD + (H), Mach et al., } 2010 \text { [35] } \\
\text { Oral } 0.36 \mathrm{mg} \text { pycnogenol } 3 \mathrm{~h} \text { prior to exercise. AD and NADH } \\
\text { increased in muscle and serum. An increase of } 17 \% \text { in physical work } \\
\text { capacity until fatigue. }\end{array}$ & Pycnogenol & 13 \\
\hline $\begin{array}{c}\text { Epigenetic and neurological effects and safety of high-dose } \\
\text { nicotinamide in patients with Friedreich's ataxia: An exploratory, } \\
\text { open-label, dose-escalation study, Libri et al., 2014 [36] } \\
\text { Oral 2-8 g nicotinamide for } 8 \text { weeks. A sustained improvement in } \\
\text { frataxin concentrations. Clinical measures showed no significant } \\
\text { changes. }\end{array}$ & Nicotinamide & 40 \\
\hline $\begin{array}{l}\text { Evidence for a direct effect of the NAD+ precursor Acipimox on muscle } \\
\text { mitochondrial function in humans, van de Weijer et al., 2014 [37] } \\
\text { Oral } 250 \mathrm{mg} \text { Acipimox for } 2 \text { weeks. A rebound rise in plasma NEFA, } \\
\text { negatively impacted insulin sensitivity. Skeletal muscle mitochondrial } \\
\text { oxidative capacity and ATP production improved. }\end{array}$ & Acipimox & 21 \\
\hline $\begin{array}{l}\text { Effect of coenzyme Q } 10 \text { plus nicotinamide adenine dinucleotide } \\
\text { supplementation on maximum heart rate after exercise testing in } \\
\text { chronic fatigue syndrome, A randomized, controlled, double-blind trial, } \\
\text { Castro-Marrero et al., } 2015 \text { [38] } \\
\text { Oral } 50 \mathrm{mg} \text { of CoQ10 and } 5 \mathrm{mg} \text { of NADH twice daily for } 8 \text { weeks. } \\
\text { NADH: } 252 \% \text { increase in PBMC. A significant reduction in max HR } \\
\text { during a cycle ergometer test at week } 8 \text { versus baseline. }\end{array}$ & CoQ10 / NADH & 80 \\
\hline $\begin{array}{l}\text { An open-label, non-randomized study of the pharmacokinetics of the } \\
\text { nutritional supplement nicotinamide riboside (NR) and its effects on } \\
\text { blood NAD+ levels in healthy volunteers, Airhart et al., } 2017 \text { [39] } \\
\text { Oral 250-1000 mg NR twice daily for } 8 \text { days. NAD+: } \sim 100 \% \text { increase in } \\
\text { whole blood. NR was safe and well-tolerated. }\end{array}$ & NR & 8 \\
\hline
\end{tabular}

Prevention of non-melanoma skin cancers with nicotinamide in transplant recipients: a case-control study, Drago et al., 2017 [40] Oral $500 \mathrm{mg}$ nicotinamide daily. Actinic keratoses (AKs) significantly decreased in size in 18/19 patients (88\%). In controls, $91 \%$ showed an increase in size or number of AKs.

Pharmacokinetics and tolerability of MB12066, a beta-lapachone

derivative targeting $\mathrm{NAD}(\mathrm{P}) \mathrm{H}$ : quinone oxidoreductase 1: two independent, double-blind, placebo-controlled, combined single and multiple ascending doses first-in-human clinical trials, Kim et al., 2017 [41]

Oral MB12066 up to a 400-mg single dose or $200 \mathrm{mg}$ daily for 7 days. MB12066 was safe and well-tolerated.

Pharmacokinetic and safety evaluation of MB12066, an NQO1 substrate, Lee et al., 2017 [42]

Oral 100 mg MB12066 twice daily. MB12066 was safe and well-tolerated.

Phase II clinical trial of nicotinamide for the treatment of mild to moderate Alzheimer's disease, Phelan et al., 2017 [43]

Oral $1500 \mathrm{mg}$ nicotinamide twice daily for 24 weeks. There were no significant effects of nicotinamide on the primary or secondary endpoints.

A randomized placebo-controlled clinical trial of nicotinamide riboside in obese men: safety, insulin-sensitivity, and lipid-mobilizing effects, Dollerup et al., 2018 [44]

Oral 1000 mg NR twice daily for 12 weeks. No improvement in insulin sensitivity, endogenous glucose production, glucose disposal and oxidation, resting energy expenditure, lipolysis, oxidation of lipids, or body composition. 
Table 1. Cont.

\begin{tabular}{|c|c|c|}
\hline Study & Intervention & $\mathbf{N}$ \\
\hline $\begin{array}{l}\text { Chronic nicotinamide riboside supplementation is well-tolerated and } \\
\text { elevates NAD + in healthy } \\
\text { middle-aged and older adults, Martens et al., 2018 [45] } \\
\text { Oral NR } 500 \text { mg twice daily. NAD+: } 60 \% \text { increase in PBMC. NR is } \\
\text { well tolerated and effectively stimulates NAD + metabolism. }\end{array}$ & NR & 30 \\
\hline $\begin{array}{c}\text { De novo NAD+ biosynthetic impairment in acute kidney injury in } \\
\text { humans, Mehr et al., } 2018 \text { [46] } \\
\text { Oral } 1 \text { or } 3 \text { g nicotinamide daily for } 3 \text { days. Nicotinamide } \\
\text { administration was not associated with increased adverse events } \\
\text { compared to placebo. }\end{array}$ & Nicotinamide & 55 \\
\hline
\end{tabular}

Effects of nicotinamide riboside on endocrine pancreatic function and incretin hormones in nondiabetic men with obesity, Dollerup et al., 2019

Oral 1000 mg NR twice daily for 12 weeks. No effect on fasting or post-glucose challenge concentrations of glucose, insulin, C-peptide, supplementation.

\begin{tabular}{|c|c|c|}
\hline $\begin{array}{c}\text { Acute nicotinamide riboside supplementation improves redox } \\
\text { homeostasis and exercise performance in old individuals: a } \\
\text { double-blind cross-over study, Dolopikou et al., } 2019 \text { [48] } \\
\text { Oral } 500 \mathrm{mg} \text { NR, one dose. NR supplementation significantly increased } \\
\text { NADH and NADPH, improved isometric peak torque by } 8 \% \text {, and } \\
\text { fatigue index by } 15 \% \text {. }\end{array}$ & NR & 24 \\
\hline $\begin{array}{c}\text { Nicotinamide riboside augments the aged human skeletal muscle } \\
\text { NAD+ metabolome and induces transcriptomic and anti-inflammatory } \\
\text { signatures, Elhassan et al., 2019 [49] } \\
\text { Oral } 1 \mathrm{~g} \text { NR daily for } 21 \text { days. NR elevated the muscle NAD+ } \\
\text { metabolome; downregulated energy metabolism and mitochondria } \\
\text { pathways without altering mitochondrial bioenergetics; depressed } \\
\text { levels of circulating inflammatory cytokines. }\end{array}$ & NR & 12 \\
\hline $\begin{array}{c}\text { Effect of oral administration of nicotinamide } \\
\text { mononucleotide on clinical parameters and } \\
\text { nicotinamide metabolite levels in healthy Japanese men, Irie et al., } 2019 \\
\text { [50] } \\
\text { Oral 100-500 mg NMN, single dose. Safe and effectively metabolized in } \\
\text { healthy men without causing any significant deleterious effects. }\end{array}$ & NMN & 10 \\
\hline $\begin{array}{l}\text { Efficacy and tolerability of EH301 for amyotrophic lateral sclerosis: A } \\
\text { randomized, double-blind, placebo-controlled human pilot study, de la } \\
\text { Rubia et al., } 2019 \text { [51] } \\
600 \mathrm{mg} \text { EH301 twice daily for } 4 \text { months. EH301 was shown to } \\
\text { significantly slow the progression of ALS relative to placebo. }\end{array}$ & EH301 & 32 \\
\hline $\begin{array}{c}\text { Resistance training increases muscle NAD+ and NADH concentrations } \\
\text { as well as NAMPT protein levels and global sirtuin activity in } \\
\text { middle-aged, overweight, untrained individuals, Lamb et al., 2020 [9] } \\
10 \text { weeks of full-body resistance training. Muscle NAD+, NADH, and } \\
\text { global SIRT activity are positively affected by resistance training in } \\
\text { middle-aged, untrained individuals. }\end{array}$ & $\begin{array}{l}\text { Resistance } \\
\text { training }\end{array}$ & 16 \\
\hline $\begin{array}{l}\text { Niacin cures systemic NAD + deficiency and } \\
\text { improves muscle performance in adult-onset } \\
\text { mitochondrial myopathy, Pirinen et al., 2020 [52] } \\
\text { Oral niacin, 750-1000 mg daily, } 4 \text { months for controls, } 10 \text { months for } \\
\text { patients. Blood NAD+ increased eightfold in controls and patients. } \\
\text { Muscle NAD+ of patients reached that of controls. Muscle strength and } \\
\text { biogenesis increased in controls and patients. Muscle metabolome of } \\
\text { patients shifted towards controls. Liver fat decreased 50\% in patients. }\end{array}$ & Niacin & 15 \\
\hline
\end{tabular}


Additionally, 24 further clinical trials were identified as relevant to the assessment of NAD+ pharmacology, none of which is yet associated with published data. Most are recruiting or in progress, and are summarized in Table 2.

Table 2. Selected clinical trials yet to publish results.

\begin{tabular}{|c|c|c|}
\hline Trial & Intervention & $\mathbf{N}$ \\
\hline $\begin{array}{l}\text { Effect of "nicotinamide mononucleotide" (NMN) on cardiometabolic } \\
\text { function (NMN) } \\
\text { NCT03151239 }\end{array}$ & NMN & 25 \\
\hline $\begin{array}{l}\text { Effect of long-term oral administration of nicotinamide mononucleotide } \\
\qquad \text { (NMN) on human health } \\
\text { UMIN000025739 }\end{array}$ & NMN & 20 \\
\hline $\begin{array}{l}\text { Assessment of the safety of long-term nicotinamide mononucleotide } \\
\text { (NMN). } \\
\text { UMIN000030609 }\end{array}$ & NMN & 30 \\
\hline $\begin{array}{l}\text { Evaluate the efficacy and safety of uthever NMN (nicotinamide } \\
\text { mononucleotide, a form of vitamin B3) (NMN) } \\
\text { NCT04228640 }\end{array}$ & NMN & 66 \\
\hline $\begin{array}{l}\text { Effects of vitamin B3 derivative nicotinamide Riboside (NR) in bone, } \\
\text { skeletal muscle and metabolic functions in aging } \\
\text { NCT03818802 }\end{array}$ & NR & 48 \\
\hline $\begin{array}{l}\text { Nicotinamide riboside for treating elevated systolic blood pressure and } \\
\text { arterial stiffness in middle-aged and older adults } \\
\text { NCT03821623 }\end{array}$ & NR & 118 \\
\hline $\begin{array}{l}\text { Nicotinamide riboside in hospitalized patients } \\
\text { NCT04110028 }\end{array}$ & NR & 84 \\
\hline $\begin{array}{l}\text { The effects of nicotinamide adenine dinucleotide (NAD) on brain } \\
\text { function and cognition (NAD) } \\
\text { NCT02942888 }\end{array}$ & NR & 46 \\
\hline $\begin{array}{l}\text { Crossover trial for nicotinamide riboside in subjective cognitive decline } \\
\text { and mild cognitive impairment } \\
\text { NCT04078178 }\end{array}$ & NR & 40 \\
\hline $\begin{array}{l}\text { Evaluation of nicotinamide riboside in the prevention of small fiber } \\
\text { axon degeneration and promotion of nerve regeneration } \\
\text { NCT03912220 }\end{array}$ & NR & 40 \\
\hline $\begin{array}{l}\text { NAD therapy for improving memory and brain blood flow in older } \\
\text { adults with mild cognitive impairment } \\
\text { NCT03482167 }\end{array}$ & NR & 58 \\
\hline $\begin{array}{l}\text { A randomized controlled trial of nicotinamide supplementation in early } \\
\text { Parkinson's disease (NOPARK) } \\
\text { NCT03568968 }\end{array}$ & NR & 400 \\
\hline $\begin{array}{l}\text { NAD-supplementation in drug-naive Parkinson's disease (NAD-PARK) } \\
\text { NCT03816020 }\end{array}$ & NR & 30 \\
\hline $\begin{array}{l}\text { Effects of vitamin B3 in patients with ataxia-telangiectasia } \\
\text { NCT03962114 }\end{array}$ & NR & 24 \\
\hline $\begin{array}{l}\text { Nicotinamide riboside in systolic heart failure } \\
\text { NCT03423342 }\end{array}$ & NR & 30 \\
\hline $\begin{array}{l}\text { Study to evaluate the effect of nicotinamide riboside on immunity } \\
\text { NCT02812238 }\end{array}$ & NR & 38 \\
\hline $\begin{array}{l}\text { Nicotinamide riboside and mitochondrial biogenesis } \\
\text { NCT03432871 }\end{array}$ & NR & 15 \\
\hline
\end{tabular}


Table 2. Cont.

\begin{tabular}{|c|c|c|}
\hline Trial & Intervention & $\mathbf{N}$ \\
\hline $\begin{array}{l}\text { Effects of nicotinamide riboside on the clinical outcome of Covid-19 in } \\
\text { the elderly (NR-COVID19) } \\
\text { NCT04407390 }\end{array}$ & NR & 100 \\
\hline $\begin{array}{l}\text { A study to evaluate the safety and health benefits of Basis }{ }^{\mathrm{TM}} \text { among } \\
\text { elderly subjects. (15BSHE) } \\
\text { NCT02678611 }\end{array}$ & $\begin{array}{c}\text { Basis (NR, } \\
\text { pterostilbene) }\end{array}$ & 120 \\
\hline $\begin{array}{l}\text { A study by ChromaDex to assess the effects of TRU NIAGEN on } \\
\text { cognitive function, mood and sleep in older adults } \\
\text { NCT03562468 }\end{array}$ & $\begin{array}{l}\text { TRU NIAGEN } \\
\text { (NR) }\end{array}$ & 40 \\
\hline $\begin{array}{l}\text { NAD Supplementation Study (NADS) } \\
\text { NCT03310034 }\end{array}$ & $\begin{array}{l}\text { Nicotinic acid, } \\
\text { nicotinamide, } \\
\text { tryptophan }\end{array}$ & 14 \\
\hline $\begin{array}{l}\text { Nicotinamide as an early Alzheimer's disease treatment (NEAT) } \\
\text { NCT03061474 }\end{array}$ & $\begin{array}{l}\text { Niacin, } \\
\text { nicotinamide }\end{array}$ & 48 \\
\hline $\begin{array}{l}\text { Study of the efficacy and safety of nicotinamide in patients with } \\
\text { Friedreich ataxia (NICOFA) } \\
\text { NCT03761511 }\end{array}$ & Nicotinamide & 225 \\
\hline $\begin{array}{l}\text { Niacin for Parkinson's disease (NAPS) } \\
\text { NCT03808961 }\end{array}$ & Niacin & 100 \\
\hline
\end{tabular}

\subsection{Summary of Studies}

Of the 36 human trials with published results identified in our literature review, 18 reported on oral administration of NAD precursors, such as nicotinamide, NMN, or NR, while 8 employed oral administration of NAD. The remainder used an eclectic mix of exercise programs, antioxidants, forms of topical, intravenous, or intramuscular administration of NAD, as well as compounds targeting NQO1 activity. Of the 36 trials, 7 assessed only pharmacokinetics, safety, or biomarkers, and 17 reported beneficial outcomes. The remaining 12 reported no benefits to patients.

Our review reveals that the upregulation of NAD has been studied for a wide range of medical conditions, only a few of which are addressed by more than one study. These conditions include acute kidney injury, Alzheimer's disease, chronic fatigue syndrome, dementia, hyperphosphatemia, hypertension, obesity, Parkinson's disease, photoaging of skin, psoriasis, skin cancers, type 1 diabetes mellitus, type 2 diabetes mellitus, and schizophrenia.

NAD levels after intervention were measured in only 11 trials, in blood samples or tissues, via quantitative methods such as colorimetric analysis. In all cases, increased NAD was observed, but the size of the effect varied widely. These changes were almost incomparable due to the current lack of standardization, as variance may be due to differences in methodology of measurement, in interventions, or other factors.

Of the completed, published trials identified in this study, only two were adequately powered. Firstly, the European Nicotinamide Diabetes Intervention Trial that employed daily supplementation of nicotinamide. The primary outcome of progression to type 1 diabetes was negative [29]. Secondly, the open-label trial of oral and infused NADH in Parkinson's disease patients by Birkmayer et al. showed a beneficial effect in $80 \%$ of the patients [23]. The effects on NAD in serum or tissues were assessed in neither of these studies. It should also be noted that the metabolism of intravenously infused NAD/NADH is currently unclear although it is likely that both metabolites are cleaved into nicotinamide and ADP-ribose by the liver, as has been demonstrated in mice [53]. It is also possible that CD38-expressing cells, such as leukocytes [54], act to degrade NAD/NADH in plasma. 


\subsubsection{Neurological and Neurodegeneration Conditions}

The earliest deliberate attempts at NAD pharmacology, as distinct from the extensive study of vitamin B3, involved the delivery of niacin or formulations of NAD in the treatment of schizophrenia, beginning in the 1960s [18-20]. This intervention was based on a variety of hypotheses linking NAD biochemistry to the neurobiological changes thought to be involved in schizophrenia. More modern hypotheses of NAD-related redox dysfunction in schizophrenia continue to be debated today; mitochondrial dysfunction and oxidative stress are thought to contribute to the pathogenesis of the condition [55]. Available reports refer to positive results in earlier studies, but the authors reported no benefits to patients resulting from their small clinical trials.

Beginning in the 1990s, NAD pharmacology was assessed as a basis for the treatment of Parkinson's disease and Alzheimer's disease [22-25], efforts that have since expanded to other forms of dementia [56]. To date, the results of clinical trials have been mixed for Parkinson's disease and largely negative for Alzheimer's disease. Further trials are in progress.

\subsubsection{Skin Conditions}

NAD upregulation prevents actinic keratosis and improves some measures of photoaging $[33,40]$. While the mechanisms of action are not fully understood, NAD is a co-factor for the PARP enzymes that play a key role in DNA repair. Skin is exposed to UV damage, causing frequent DNA breaks. Improving PARP function, and thus improving DNA repair, might protect from precancerous skin lesions and other consequences of photoaging. This mechanism may also influence the skin pathology associated with dysregulated skin cell division in conditions, such as psoriasis [32].

\subsubsection{Metabolic Conditions}

Only limited data are available for the use of NAD boosters in the treatment of metabolic conditions, such as obesity and metabolic syndrome. While some studies report improvement in lipid profile, exercise capacity, and muscle fiber composition despite a sedentary lifestyle [37,49], others show no benefit of supplementation in the prevention of type 1 diabetes [29], and no improvements in insulin resistance [44,47].

\subsubsection{Potential Side Effects}

No study reported severe side effects, supporting the thesis that these interventions are likely to be relatively safe for human use. Multiple widely used over-the-counter supplements increase NAD levels, including niacin, NR, and NMN, and vitamin B3 supplementation have been in use for many years. Thus, it seems likely that side effects linked to interventions that target NAD metabolism more likely arise from impurities rather than the supplements themselves, since this industry generally operates without rigorous control of quality and standardization.

In short term experiments, high doses of nicotinamide cause hepatic toxicity [57]. High doses of niacin cause headaches, skin flushing, and dizziness [58]. These effects occur at doses much higher than those used in clinical trials and have so far not been reported in the limited number of studies of NAD pharmacology to date.

Long-term side-effects of NAD upregulation, harder to detect and quantify, may exist and sustained high doses of vitamin B3 compounds may have long-term side-effects. Excessive intake of niacin or nicotinamide may contribute to the development of Parkinson's disease [57]. Nicotinamide may contribute to the development of diabetes, but animal data here contradict the human trial results showing no such effect [57]. Additionally, high doses of NR aggravate insulin resistance and produce white adipose tissue dysfunction in mice [59].

Another possible concern following chronic high-level administration of nicotinamide is the depletion of methyl groups. It has been reported that nicotinamide induces nicotinamide-N-methyltransferase which catalyzes the methylation of nicotinamide. This may cause 
secondary problems by consuming methyl groups that are required elsewhere to maintain cellular homeostasis [60].

NAD upregulation may also worsen the senescence-associated secretory phenotype (SASP) produced by senescent cells in old tissues. A proposed mechanism for this side-effect involves suppression of AMPK and p53, leading to stimulation of NF- $\mathrm{BB}$ via p38 MAPK and increased expression of inflammatory cytokines [61]. The burden of cellular senescence increases with age, and the SASP contributes to diverse pathologies of aging [62] An alternative hypothesis is that activation of a stronger SASP by NAD boosters may lead to enhanced clearance of senescent cells and an anti-aging effect, but supporting data, in either case, is presently very limited.

Supporting evidence for these potential long-term issues is sparse at best and entirely lacking in some cases. Given the fact that anti-aging interventions are likely to target comparatively healthy, comparatively younger individuals, quantification of potential long-term adverse effects will be critical to ensure that these interventions are safe.

\section{Discussion}

NAD is required for critical cellular pathways involving NAD-consuming enzymes (sirtuins, PARPs and CD38) and NAD-utilizing but non consuming enzymes (using the NAD/NADH redox couple). These two classes of enzymes rely on effective NAD levels, giving this latter metabolite a broad influence over cellular biochemistry relevant to health, disease and aging.

\subsection{Gaps in the Knowledge of NAD}

NAD levels decrease with age in tissues throughout the body. While numerous mechanisms have been proposed to explain this observation, there is still only an incomplete understanding of this phenomenon. Investigations of NAD biochemistry have largely focused on proximate causes, meaning changes in the expression of proteins that are rate-limiting in NAD synthesis and salvage pathways. For example, nicotinamide phosphoribosyltransferase (NAMPT) levels fall with age, and NAMPT is the rate-limiting enzyme for the pathway responsible for synthesizing NAD from nicotinamide [63].

Incomplete knowledge about the causative mechanisms of diminished NAD with aging leaves open the question of its connection to deeper causes of degenerative aging cataloged in the hallmarks of aging [64] and strategies for engineered negligible senescence (SENS) [65]. Further research is required to understand whether or not NAD pharmacology is in fact an efficient point of intervention, or whether deeper causes should be targeted instead.

Most researchers consider that for NAD or NAD precursors to exert beneficial effects, they must be taken up by cells to participate in pathways relevant to aging and age-related conditions. It remains to be robustly determined as to how oral or intravenous administration of the NAD produces benefits, as comparatively little work has taken place to characterize NAD+ transport into cells. While connexin 43 has been identified as a NAD+ transporter in a few cell lines and primary cell cultures [66], few groups have published on this topic. Evidence exists for extracellular NAD to influence processes relevant to osteoporosis and immunosenescence $[67,68]$. The literature points to participation in numerous other mechanisms of interest, as well.

Notably, in this context, NMN enters cells via the Slc12a8 transporter [69]. Prior to this, it could only be hypothesized that such a mechanism existed, based on observing the results of NMN supplementation [70]. More remains to be discovered on how extracellular NAD and NAD precursors interact with cells, and such discoveries may resolve outstanding questions about the use of NAD or its precursors as an intervention.

\subsection{Viruses and COVID-19}

Cell and animal studies show that NAD is involved in regulating immune system activity [71,72]. Thus, NAD+ upregulation may ameliorate aspects of age-related immunosenescence and inflammaging [14], 
protect against viral disease and help the elderly to mount an immune response to vaccines. A trial of NR supplementation for COVID-19 in the elderly is recruiting [73].

However, although the animal evidence is promising, more human clinical studies are required. We do not know which forms of NAD pharmacology work to address immune function, nor is the dose range established. Further, it is unknown as to whether it would be beneficial to upregulate NAD via supplements as an immune booster for the entire elderly population, or only as a specific treatment for certain medical conditions.

\section{Conclusions}

Based on the human trials conducted to date, NAD pharmacology is a promising treatment strategy that is likely to be safe for human use. However, despite several decades of active investigation, there is still only suggestive evidence, in the form of a few successful and sufficiently powered clinical trials, for NAD upregulation to be effective for any of the many potential indications where it may benefit patients.

Further trials are justified: about half of the published trials identified in our review reported patient benefits. Most of the indications tested require further studies for replication because only a single trial has taken place.

In general, it is the case that more and larger studies are required to produce robust data in support of NAD pharmacology. This includes in particular studies in which different forms of NAD upregulation are compared consistently with one another. For example, exercise programs tailored to older individuals may be more effective than all of the existing approaches to NAD pharmacology. Whether or not this is the case is one of the more important questions for the research community to answer.

Author Contributions: Conceptualization, D.R.; methodology, D.R., R. and E.V.; data curation, D.R. and R.; writing, D.R., R. and E.V. All authors have read and agreed to the published version of the manuscript.

Funding: This research received no external funding.

Conflicts of Interest: D.R. is a Chief Scientific Officer at Health, Longevity, Performance Optimisation Institute, a medical clinic and research institute focused on longevity and preventative medicine. Reason is a founder of Repair Biotechnologies, focused on novel drug targets for aging. E.V. is a founder and shareholder of Napa Therapeutics, and a consultant to Seneque, which are both involved in commercial efforts in NAD metabolism.

\section{References}

1. Harden, A.; Young, W.J.; Martin, C.J. The alcoholic ferment of yeast-juice. Part II-The coferment of yeast-juice. In Proceedings of the Royal Society of London. Series B, Containing Papers of a Biological Character; The Royal Society Publishing: London, UK, 1906; Volume 78, pp. 369-375. [CrossRef]

2. Chambon, P.; Weill, J.D.; Mandel, P. Nicotinamide mononucleotide activation of a new DNA-dependent polyadenylic acid synthesizing nuclear enzyme. Biochem. Biophys. Res. Commun. 1963, 11, 39-43. [CrossRef]

3. Imai, S.; Armstrong, C.M.; Kaeberlein, M.; Guarente, L. Transcriptional silencing and longevity protein Sir2 is an NAD-dependent histone deacetylase. Nature 2000, 403, 795-800. [CrossRef] [PubMed]

4. Rajman, L.; Chwalek, K.; Sinclair, D.A. Therapeutic potential of NAD-boosting molecules: The in vivo evidence. Cell Metab. 2018, 27, 529-547. [CrossRef] [PubMed]

5. Verdin, E. NAD+ in aging, metabolism, and neurodegeneration. Science 2015, 350, 1208-1213. [CrossRef]

6. Magni, G.; Amici, A.; Emanuelli, M.; Orsomando, G.; Raffaelli, N.; Ruggieri, S. Enzymology of NAD+ homeostasis in man. Cell. Mol. Life Sci. 2004, 61, 19-34. [CrossRef]

7. Camacho-Pereira, J.; Tarragó, M.G.; Chini,C.C.; Nin, V.; Escande, C.; Warner, G.M.; Puranik, A.S.; Schoon, R.A.; Reid, J.M.; Galina, A.; et al. CD38 Dictates Age-Related NAD Decline and Mitochondrial Dysfunction through an SIRT3-Dependent Mechanism. Cell Metab. 2016, 23, 1127-1139. [CrossRef]

8. Trammell, S.A.; Schmidt, M.S.; Weidemann, B.J.; Redpath, P.; Jaksch, F.; Dellinger, R.W.; Li, Z.; Abel, E.D.; Migaud, M.E.; Brenner, C. Nicotinamide riboside is uniquely and orally bioavailable in mice and humans. Nat. Commun. 2016, 7, 1-14. [CrossRef] 
9. Lamb, D.A.; Moore, J.H.; Mesquita, P.H.C.; Smith, M.A.; Vann, C.G.; Osburn, S.C.; Fox, C.D.; Lopez, H.L.; Ziegenfuss, T.N.; Huggins, K.W.; et al. Resistance training increases muscle NAD+ and NADH concentrations as well as NAMPT protein levels and global sirtuin activity in middle-aged, overweight, untrained individuals. Aging 2020, 12, 9447-9460. [CrossRef]

10. Revollo, J.R.; Grimm, A.A.; Imai, S. The regulation of nicotinamide adenine dinucleotide biosynthesis by Nampt/PBEF/visfatin in mammals. Curr. Opin. Gastroenterol. 2007, 23, 164-170. [CrossRef]

11. Escande, C.; Nin, V.; Price, N.L.; Capellini, V.; Gomes, A.P.; Barbosa, M.T.; O’Neil, L.; White, T.A.; Sinclair, D.A.; Chini, E.N. Flavonoid Apigenin Is an Inhibitor of the NAD+ase CD38: Implications for Cellular NAD+ Metabolism, Protein Acetylation, and Treatment of Metabolic Syndrome. Diabetes 2013, 62, 1084-1093. [CrossRef]

12. Carlson, L.A. Nicotinic acid: The broad-spectrum lipid drug. A 50th anniversary review. J. Intern. Med. 2005, 258, 94-114. [CrossRef] [PubMed]

13. D'Andrea, E.; Hey, S.P.; Ramirez, C.L.; Kesselheim, A.S. Assessment of the Role of Niacin in Managing Cardiovascular Disease Outcomes: A Systematic Review and Meta-analysis. JAMA Netw. Open 2019, 2, e192224. [CrossRef] [PubMed]

14. Minhas, P.S.; Liu, L.; Moon, P.K.; Joshi, A.U.; Dove, C.; Mhatre, S.; Contrepois, K.; Wang, Q.; Lee, B.A.; Coronado, M.; et al. Macrophage de novo NAD+ synthesis specifies immune function in aging and inflammation. Nat. Immunol. 2019, 20, 50-63. [CrossRef]

15. Biefer, H.R.C.; Vasudevan, A.; Elkhal, A. Aspects of Tryptophan and Nicotinamide Adenine Dinucleotide in Immunity: A New Twist in an Old Tale. Int. J. Tryptophan Res. 2017, 10. [CrossRef]

16. Omran, H.M.; Almaliki, M.S. Influence of NAD+ as an ageing-related immunomodulator on COVID 19 infection: A hypothesis. J. Infect. Public Health 2020. [CrossRef]

17. Savitz, J. The Kynurenine Pathway: A Finger in Every Pie. Mol. Psychiatry 2020, 25, 131-147. [CrossRef]

18. Kline, N.S.; Barclay, G.L.; Cole, J.O.; Esser, A.H.; Lehmann, H.; Wittenborn, J.R. Controlled Evaluation of Nicotinamide Adenine Dinucleotide in the Treatment of Chronic Schizophrenic Patients. Br. J. Psychiatry 1967, 113, 731-742. [CrossRef]

19. Kline, N.S.; Barclay, G.L.; Esser, A.H.; Cole, J.O.; Lehmann, H.E.; Wittenborn, J.R. Diphosphopyridine Nucleotide in the Treatment of Schizophrenia. JAMA 1967, 200, 881-882. [CrossRef]

20. Meltzer, H.; Shader, R.; Grinspoon, L. The behavioral effects of nicotinamide adenine dinucleotide in chronic schizophrenia. Psychopharmacologia 1969, 15, 144-152. [CrossRef]

21. Ban, T.A. Nicotinic Acid in the Treatment of Schizophrenias. NPS 1975, 1, 133-145. [CrossRef]

22. Birkmayer, W.; Birkmayer, G.J.; Vrecko, K.; Mlekusch, W.; Paletta, B.; Ott, E. The coenzyme nicotinamide adenine dinucleotide (NADH) improves the disability of parkinsonian patients. J. Neural Transm. Park. Dis. Dement. Sect. 1989, 1, 297-302. [CrossRef] [PubMed]

23. Birkmayer, J.G.; Vrecko, C.; Volc, D.; Birkmayer, W. Nicotinamide adenine dinucleotide (NADH)—A new therapeutic approach to Parkinson's disease. Comparison of oral and parenteral application. Acta Neurol. Scand. 1993, 146, 32-35.

24. Dizdar, N.; Kågedal, B.; Lindvall, B. Treatment of Parkinson's disease with NADH. Acta Neurol. Scand. 1994, 90, 345-347. [CrossRef] [PubMed]

25. Birkmayer, J.G. Coenzyme nicotinamide adenine dinucleotide: New therapeutic approach for improving dementia of the Alzheimer type. Ann. Clin. Lab. Sci. 1996, 26, 1-9. [PubMed]

26. Hageman, G.J.; Stierum, R.H.; van Herwijnen, M.H.M.; van der Veer, M.S.E.; Kleinjans, J.C.S. Nicotinic acid supplementation: Effects on niacin status, cytogenetic damage, and poly(ADP-ribosylation) in lymphocytes of smokers. Nutr. Cancer 1998, 32, 113-120. [CrossRef] [PubMed]

27. Forsyth, L.M.; Preuss, H.G.; MacDowell, A.L.; Chiazze, L.; Birkmayer, G.D.; Bellanti, J.A. Therapeutic effects of oral NADH on the symptoms of patients with chronic fatigue syndrome. Ann. Allergy Asthma Immunol. 1999, 82, 185-191. [CrossRef]

28. Rainer, M.; Kraxberger, E.; Haushofer, M.; Mucke, H.A.M.; Jellinger, K.A. No evidence for cognitive improvement from oral nicotinamide adenine dinucleotide (NADH) in dementia. J. Neural Transm. 2000, 107, 1475-1481. [CrossRef] [PubMed]

29. Gale, E.A. European Nicotinamide Diabetes Intervention Trial (ENDIT): A randomised controlled trial of intervention before the onset of type 1 diabetes. Lancet 2004, 363, 925-931. [CrossRef] 
30. Osar, Z.; Samanci, T.; Demirel, G.Y.; Damci, T.; Ilkova, H. Nicotinamide Effects Oxidative Burst Activity of Neutrophils in Patients with Poorly Controlled Type 2 Diabetes Mellitus. Exp. Diabesity Res. 2004, 5. [CrossRef]

31. Takahashi, Y.; Tanaka, A.; Nakamura, T.; Fukuwatari, T.; Shibata, K.; Shimada, N.; Ebihara, I.; Koide, H. Nicotinamide suppresses hyperphosphatemia in hemodialysis patients. Kidney Int. 2004, 65, 1099-1104. [CrossRef]

32. Wozniacka, A.; Szajerski, P.; Adamus, J.; Gebicki, J.; Sysa-Jedrzejowska, A. In Search for New Antipsoriatic Agents: NAD+ Topical Composition. SPP 2007, 20, 37-42. [CrossRef]

33. Jacobson, E.L.; Kim, H.; Kim, M.; Williams, J.D.; Coyle, D.L.; Coyle, W.R.; Grove, G.; Rizer, R.L.; Stratton, M.S.; Jacobson, M.K. A topical lipophilic niacin derivative increases NAD, epidermal differentiation and barrier function in photodamaged skin. Exp. Dermatol. 2007, 16, 490-499. [CrossRef] [PubMed]

34. Costford, S.R.; Bajpeyi, S.; Pasarica, M.; Albarado, D.C.; Thomas, S.C.; Xie, H.; Church, T.S.; Jubrias, S.A.; Conley, K.E.; Smith, S.R. Skeletal muscle NAMPT is induced by exercise in humans. Am. J. Physiol. Endocrinol. Metab. 2009, 298, E117-E126. [CrossRef] [PubMed]

35. Mach, J.; Midgley, A.W.; Dank, S.; Grant, R.S.; Bentley, D.J. The Effect of Antioxidant Supplementation on Fatigue during Exercise: Potential Role for NAD+(H). Nutrients 2010, 2, 319-329. [CrossRef]

36. Libri, V.; Yandim, C.; Athanasopoulos, S.; Loyse, N.; Natisvili, T.; Law, P.P.; Chan, P.K.; Mohammad, T.; Mauri, M.; Tam, K.T.; et al. Epigenetic and neurological effects and safety of high-dose nicotinamide in patients with Friedreich's ataxia: An exploratory, open-label, dose-escalation study. Lancet 2014, 384, 504-513. [CrossRef]

37. Van De Weijer, T.; Phielix, E.; Bilet, L.; Williams, E.G.; Ropelle, E.R.; Bierwagen, A.; Livingstone, R.; Nowotny, P.; Sparks, L.M.; Paglialunga, S.; et al. Evidence for a Direct Effect of the NAD+ Precursor Acipimox on Muscle Mitochondrial Function in Humans. Diabetes 2015, 64, 1193-1201. [CrossRef]

38. Castro-Marrero, J.; Sáez-Francàs, N.; Segundo, M.J.; Calvo, N.; Faro, M.; Aliste, L.; de Sevilla, T.F.; Alegre, J. Effect of coenzyme Q10 plus nicotinamide adenine dinucleotide supplementation on maximum heart rate after exercise testing in chronic fatigue syndrome-A randomized, controlled, double-blind trial. Clin. Nutr. 2016, 35, 826-834. [CrossRef]

39. Airhart, S.E.; Shireman, L.M.; Risler, L.J.; Anderson, G.D.; Nagana Gowda, G.A.; Raftery, D.; Tian, R.; Shen, D.D.; O'Brien, K.D. An open-label, non-randomized study of the pharmacokinetics of the nutritional supplement nicotinamide riboside (NR) and its effects on blood NAD+ levels in healthy volunteers. PLoS ONE 2017, 12, e0186459. [CrossRef]

40. Drago, F.; Ciccarese, G.; Cogorno, L.; Calvi, C.; Marsano, L.A.; Parodi, A. Prevention of non-melanoma skin cancers with nicotinamide in transplant recipients: A case-control study. Eur. J. Dermatol. 2017, 27, 382-385. [CrossRef]

41. Kim, S.; Lee, S.; Cho, J.-Y.; Yoon, S.H.; Jang, I.-J.; Yu, K.-S. Pharmacokinetics and tolerability of MB12066, a beta-lapachone derivative targeting NAD(P)H:quinone oxidoreductase 1: Two independent, double-blind, placebo-controlled, combined single and multiple ascending dose first-in-human clinical trials. Drug Des. Dev. Ther. 2017, 11, 3187-3195. [CrossRef]

42. Lee, H.W.; Seong, S.J.; Ohk, B.; Kang, W.Y.; Gwon, M.R.; Kim, B.K.; Kim, H.J.; Yoon, Y.R. Pharmacokinetic and safety evaluation of MB12066, an NQO1 substrate. Drug Des. Dev. Ther. 2017, 11, 2719-2725. [CrossRef] [PubMed]

43. Phelan, M.J. Phase II Clinical Trial of Nicotinamide for the Treatment of Mild to Moderate Alzheimer's Disease. Available online: https://clinmedjournals.org/articles/jgmg/journal-of-geriatric-medicine-and-gerontologyjgmg-3-021.php?jid=jgmg (accessed on 19 June 2020).

44. Dollerup, O.L.; Christensen, B.; Svart, M.; Schmidt, M.S.; Sulek, K.; Ringgaard, S.; Stødkilde-Jørgensen, H.; Møller, N.; Brenner, C.; Treebak, J.T.; et al. A randomized placebo-controlled clinical trial of nicotinamide riboside in obese men: Safety, insulin-sensitivity, and lipid-mobilizing effects. Am. J. Clin. Nutr. 2018, 108, 343-353. [CrossRef]

45. Martens, C.R.; Denman, B.A.; Mazzo, M.R.; Armstrong, M.L.; Reisdorph, N.; McQueen, M.B.; Chonchol, M.; Seals, D.R. Chronic nicotinamide riboside supplementation is well-tolerated and elevates NAD+ in healthy middle-aged and older adults. Nat. Commun. 2018, 9, 1286. [CrossRef] [PubMed] 
46. Mehr, A.P.; Tran, M.T.; Ralto, K.M.; Leaf, D.E.; Washco, V.; Messmer, J.; Lerner, A.; Kher, A.; Kim, S.H.; Khoury, C.C.; et al. De novo NAD+ biosynthetic impairment in acute kidney injury in humans. Nat. Med. 2018, 24, 1351-1359. [CrossRef] [PubMed]

47. Dollerup, O.L.; Trammell, S.A.; Hartmann, B.; Holst, J.J.; Christensen, B.; Møller, N.; Gillum, M.P.; Treebak, J.T.; Jessen, N. Effects of Nicotinamide Riboside on Endocrine Pancreatic Function and Incretin Hormones in Nondiabetic Men with Obesity. J. Clin. Endocrinol. Metab. 2019, 104, 5703-5714. [CrossRef]

48. Dolopikou, C.F.; Kourtzidis, I.A.; Margaritelis, N.V.; Vrabas, I.S.; Koidou, I.; Kyparos, A.; Theodorou, A.A.; Paschalis, V.; Nikolaidis, M.G. Acute nicotinamide riboside supplementation improves redox homeostasis and exercise performance in old individuals: A double-blind cross-over study. Eur. J. Nutr. 2020, 59, 505-515. [CrossRef]

49. Elhassan, Y.S.; Kluckova, K.; Fletcher, R.S.; Schmidt, M.S.; Garten, A.; Doig, C.L.; Cartwright, D.M.; Oakey, L.; Burley, C.V.; Jenkinson, N.; et al. Nicotinamide Riboside Augments the Aged Human Skeletal Muscle NAD+ Metabolome and Induces Transcriptomic and Anti-inflammatory Signatures. Cell Rep. 2019, 28, 1717-1728. [CrossRef]

50. Irie, J.; Inagaki, E.; Fujita, M.; Nakaya, H.; Mitsuishi, M.; Yamaguchi, S.; Yamashita, K.; Shigaki, S.; Ono, T.; Yukioka, H.; et al. Effect of oral administration of nicotinamide mononucleotide on clinical parameters and nicotinamide metabolite levels in healthy Japanese men. Endocr. J. 2020, 67, 153-160. [CrossRef]

51. De la Rubia, J.E.; Drehmer, E.; Platero, J.L.; Benlloch, M.; Caplliure-Llopis, J.; Villaron-Casales, C.; de Bernardo, N.; AlarcÓn, J.; Fuente, C.; Carrera, S.; et al. Efficacy and tolerability of EH301 for amyotrophic lateral sclerosis: A randomized, double-blind, placebo-controlled human pilot study. Amyotroph. Lateral Scler. Front. Degener. 2019, 20, 115-122. [CrossRef]

52. Pirinen, E.; Auranen, M.; Khan, N.A.; Brilhante, V.; Urho, N.; Pessia, A.; Hakkarainen, A.; Kuula, J.; Heinonen, U.; Schmidt, M.S.; et al. Niacin Cures Systemic NAD+ Deficiency and Improves Muscle Performance in Adult-Onset Mitochondrial Myopathy. Cell Metab. 2020, 31, 1078-1090. [CrossRef]

53. Liu, L.; Su, X.; Quinn, W.J., III; Hui, S.; Krukenberg, K.; Frederick, D.W.; Redpath, P.; Zhan, L.; Chellappa, K.; White, E.; et al. Quantitative Analysis of NAD Synthesis-Breakdown Fluxes. Cell Metab. 2018, 27, 1067-1080. [CrossRef]

54. Zocchi, E.; Franco, L.; Guida, L.; Benatti, U.; Bargellesi, A.; Malavasi, F.; Lee, H.C.; DeFlora, A. A Single Protein Immunologically Identified as CD38 Displays NAD+ Glycohydrolase, ADP-Ribosyl Cyclase and Cyclic ADP-Ribose Hydrolase Activities at the Outer Surface of Human Erythrocytes. Biochem. Biophys. Res. Commun. 1993, 196, 1459-1465. [CrossRef]

55. Kim, S.Y.; Cohen, B.M.; Chen, X.; Lukas, S.E.; Shinn, A.K.; Yuksel, A.C.; Li, T.; Du, F.; Öngür, D. Redox Dysregulation in Schizophrenia Revealed by in vivo NAD+/NADH Measurement. Schizophr. Bull. 2017, 43, 197-204. [CrossRef] [PubMed]

56. Lautrup, S.; Sinclair, D.A.; Mattson, M.P.; Fang, E.F. NAD+ in Brain Aging and Neurodegenerative Disorders. Cell Metab. 2019, 30, 630-655. [CrossRef] [PubMed]

57. Rolfe, H.M. A review of nicotinamide: Treatment of skin diseases and potential side effects. J. Cosmet. Dermatol. 2014, 13, 324-328. [CrossRef] [PubMed]

58. Kamanna, V.S.; Ganji, S.H.; Kashyap, M.L. The mechanism and mitigation of niacin-induced flushing. Int. J. Clin. Pract. 2009, 63, 1369-1377. [CrossRef]

59. Shi, W.; Hegeman, M.A.; Doncheva, A.; Bekkenkamp-Grovenstein, M.; de Boer, V.C.J.; Keijer, J. High Dose of Dietary Nicotinamide Riboside Induces Glucose Intolerance and White Adipose Tissue Dysfunction in Mice Fed a Mildly Obesogenic Diet. Nutrients 2019, 11, 2439. [CrossRef]

60. Williams, A.C.; Hill, L.J.; Ramsden, D.B. Nicotinamide, NAD $(\mathrm{P})(\mathrm{H})$, and Methyl-Group Homeostasis Evolved and Became a Determinant of Ageing Diseases: Hypotheses and Lessons from Pellagra. Curr. Gerontol. Geriatr. Res. 2012, 2012. [CrossRef]

61. Mendelsohn, A.R.; Larrick, J.W. Interacting NAD+ and Cell Senescence Pathways Complicate Antiaging Therapies. Rejuvenation Res. 2019, 22, 261-266. [CrossRef]

62. Coppé, J.-P.; Desprez, P.-Y.; Krtolica, A.; Campisi, J. The Senescence-Associated Secretory Phenotype: The Dark Side of Tumor Suppression. Annu. Rev. Pathol. Mech. Dis. 2010, 5, 99-118. [CrossRef]

63. Imai, S.; Guarente, L. NAD+ and Sirtuins in Aging and Disease. Trends Cell Biol. 2014, 24, 464-471. [CrossRef] [PubMed] 
64. López-Otín, C.; Blasco, M.A.; Partridge, L.; Serrano, M.; Kroemer, G. The Hallmarks of Aging. Cell 2013, 153, 1194-1217. [CrossRef] [PubMed]

65. Bartke, A.; Campisi, J.; Heward, C.B.; Mccarter, R.J.; Stock, G. Time to Talk SENS: Critiquing the Immutability of Human Aging. Ann. N. Y. Acad. Sci. 2002, 959, 452-462. [CrossRef]

66. Bruzzone, S.; Guida, L.; Zocchi, E.; Franco, L.; Flora, A.D. Connexin 43 hemichannels mediate Ca2+-regulated transmembrane NAD+ fluxes in intact cells. FASEB J. 2001, 15, 10-12. [CrossRef] [PubMed]

67. Haag, F.; Adriouch, S.; Braß, A.; Jung, C.; Möller, S.; Scheuplein, F.; Bannas, P.; Seman, M.; Koch-Nolte, F. Extracellular NAD and ATP: Partners in immune cell modulation. Purinergic Signal. 2007, 3, 71-81. [CrossRef] [PubMed]

68. Iqbal, J.; Zaidi, M. Extracellular NAD+ Metabolism Modulates Osteoclastogenesis. Biochem. Biophys. Res. Commun. 2006, 349, 533-539. [CrossRef]

69. Grozio, A.; Mills, K.F.; Yoshino, J.; Bruzzone, S.; Sociali, G.; Tokizane, K.; Lei, H.C.; Cunningham, R.; Sasaki, Y.; Migaud, M.E.; et al. Slc12a8 is a nicotinamide mononucleotide transporter. Nat. Metab. 2019, 1, 47-57. [CrossRef]

70. Long-Term Administration of Nicotinamide Mononucleotide Mitigates Age-Associated Physiological Decline in Mice: Cell Metabolism. Available online: https://www.cell.com/cell-metabolism/fulltext/ S1550-4131(16)30495-8?_returnURL=https\%3A\%2F\%2Flinkinghub.elsevier.com\%2Fretrieve\%2Fpii\% 2FS1550413116304958\%3Fshowall\%3Dtrue (accessed on 26 June 2020).

71. Singhal, A.; Cheng, C.Y. Host NAD+ metabolism and infections: Therapeutic implications. Int. Immunol. 2019, 31, 59-67. [CrossRef]

72. Grahnert, A.; Grahnert, A.; Klein, C.; Schilling, E.; Wehrhahn, J.; Hauschildt, S. Review: NAD+: A modulator of immune functions. Innate Immun. 2011, 17, 212-233. [CrossRef]

73. Effects of Nicotinamide Riboside on the Clinical Outcome of Covid-19 in the Elderly-Full Text View-ClinicalTrials.gov. Available online: https://clinicaltrials.gov/ct2/show/NCT04407390 (accessed on 26 June 2020).

(C) 2020 by the authors. Licensee MDPI, Basel, Switzerland. This article is an open access article distributed under the terms and conditions of the Creative Commons Attribution (CC BY) license (http://creativecommons.org/licenses/by/4.0/). 